\title{
Quantification of furanoheliangolides by HPLC and GC
}

\author{
Pierre Alexandre dos Santos, Izabel Cristina Casanova Turati, José Carlos Tomaz, \\ Norberto Peporine Lopes*
}

Departamento de Física e Química, Faculdade de Ciências Farmacêuticas de Ribeirão Preto

\author{
*Correspondence: \\ N.P. Lopes \\ Departamento de Física e Química \\ Faculdade de Ciências Farmacêuticas - \\ USP/Ribeirão Preto \\ Av. do Café, s/n \\ 14040-903 - Ribeirão Preto - SP \\ E-mail: npelopes@fcfrp.usp.br
}

The development and comparison of two analytical methods (HPLC and GC) for the quantification of the most common furanoheliangolides from Lychnophora is reported in this paper. Both methods are sensitive and suitable for quantification of these metabolites.

\section{INTRODUCTION}

The genus Lychnophora is endemic to Brazil (Semir, 1991) and the hydro-alcoholic extract of leaves and the inflorescence of some species are used as analgesic and anti-inflammatory agents (Cerquiera et al., 1987; De Oliveira et al., 1996). Furanoheliangolides are the major secondary metabolites of Lychnophora (Bohlmann et al., 1982), and exhibit several biological activities. A recent study has revealed that these compounds modulate the inflammatory process by inhibition of the transcription of the factor NF-kB by selective alkylating the p65 sub-unit (Rüngeler et al., 1999). Despite its use in Brazilian folk medicine and the commercial value of Lychnophora species as analgesic and anti-inflammatory agents, some of them do not accumulate furanoheliangolides and preliminary results demonstrate seasonal and circadian variation in this metabolism. The literature reports the determination of lactones using HPLC and GC and both systems have been used for studying lactones on an analytical scale (Leven, Willuhn, 1987; Dolman et al., 1992), presenting some limitations concerning separation time or peak resolution. The aim of this work was to develop an analytical methodology in HPLC and GC to monitor differences in furanoheliangolide metabolism. In this study the most common sesquiterpene lactones that occur in the genus
Lychnophora: goyazensolide centratherin, lychnopholide, eremantholide C, 15-deoxygoyazensolide and 15 $\alpha-4,5-$ dihydroeremantholide C (Figure 1) were analyzed.

\section{MATERIAL AND METHODS}

\section{Reagents and standard solutions preparation}

All solvents used were either of analytical or HPLC grade. The sesquiterpene lactones analyzed (Figure 1) were previously isolated from species of Lychnophora in our laboratory (Vichnewski et al., 1989; Borella et al., 1992; Lunardello et al., 1995) .

Standard solutions of each sesquiterpene lactone under study (Figure 1) were prepared in methanol for HPLC analysis and in dichloromethane for GC analysis.

Coumarin was added as an internal standard both for the HPLC and GC analysis.

\section{High-performance liquid chromatography}

In this study, a Shimadzu LC-6A liquid chromatograph (Shimadzu, Kyoto, Japan) equipped with a Rheodyne injector fitted with a $20 \mathrm{~mL}$ loop, CR-6A integrator, SCL-6B system controller and an SPD-6AV UV detector set at $265 \mathrm{~nm}$ was used. The analytical column was a reversed-phase Shim-Pack ODS, $250 \times 4.6$ mm I.D., 


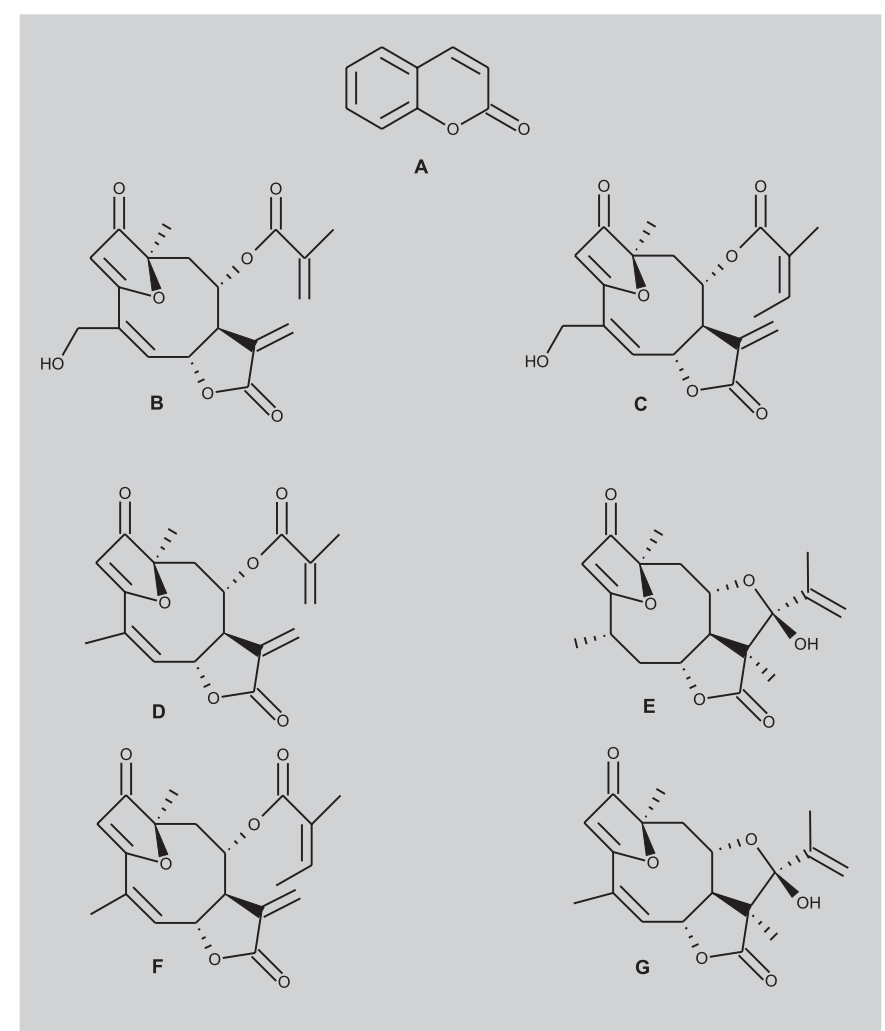

FIGURE 1 - Structures of (A) coumarin (internal standard); (B) goyazensolide; (C) centratherin; (D) 15deoxygoyazensolide; (E) 15a-4,5-dihydroeremantholide C; (F) lychnopholide; (G) eremantholide C

$5 \mu \mathrm{m}$, from Shimadzu, fitted with a guard column $(10 \times 4.6$ $\mathrm{mm}$ I.D.) packed with similar material (Merck, Darmstadt, Germany). The mobile phase used was a mixture of $\mathrm{MeOH}: \mathrm{H}_{2} \mathrm{O}$. The mobile phase gradient program was as follows: star at $30 \% \mathrm{MeOH}$, increasing to $60 \% \mathrm{MeOH}$ in 15 min, held constant until $40 \mathrm{~min}$, then return to $30 \% \mathrm{MeOH}$ in $5 \mathrm{~min}$. The next sample was injected after a further $5 \mathrm{~min}$. The flow-rate was $1.0 \mathrm{~mL} \mathrm{~min}^{-1}$, at room temperature. The injection volume was $20 \mu \mathrm{L}$.

\section{Gas chromatography}

Gas chromatography was performed on a Hewlett Packard GC 5890 Series II (Wilmington, DE., USA) using a HP-1 column $(30 \mathrm{~m} \times 0.25 \mathrm{~mm} \times 0.25 \mu \mathrm{m})$, FID detector at $300{ }^{\circ} \mathrm{C}$, manual injector at $250{ }^{\circ} \mathrm{C}$ and hydrogen as carrier gas (linear velocity $39 \mathrm{~cm} / \mathrm{s}$ ). Column oven temperature conditions as follows: initial temperature $100{ }^{\circ} \mathrm{C}$, held for $1 \mathrm{~min}$ then increased at $9^{\circ} \mathrm{C} / \mathrm{min}$ to $225^{\circ} \mathrm{C}$, then held constant for $5 \mathrm{~min}$ and increased at $3{ }^{\circ} \mathrm{C} / \mathrm{min}$ to $280^{\circ} \mathrm{C}$, where it was held constant for $15 \mathrm{~min}$, cool down to $100^{\circ} \mathrm{C}$ in $2.2 \mathrm{~min}$, and finally held constant for $4 \mathrm{~min}$.
$2 \mu \mathrm{L}$ of the samples were injected on the column, at a split ratio of 1:90.

\section{RESULTS AND DISCUSSION}

The HPLC separation is shown in Figure 2 and the corresponding structures can be seen in Figure 1. All six lactones could be well separated within less then $40 \mathrm{~min}$. According to the method of Passreiter (1998), an isocratic system showed better results for the quantitative determination of furanoheliangolides in Neurolaena lobata, but in the present study a gradient was used for better resolution of the peaks.

Furanoheliangolides could be detected at very low concentrations, considering that only $20 \mu \mathrm{L}$ of the sample were injected. All compounds were easily detectable from concentrations of $1.5 \mu \mathrm{g} \mathrm{mL}^{-1}$ upwards, and the results are highly reproducible. Earlier a quantitative method by HPLC was used to quantify sesquiterpene lactones containing a $\alpha$-methylenebutyrolactone group in Tanacetum parthenium. However, prior derivatization was

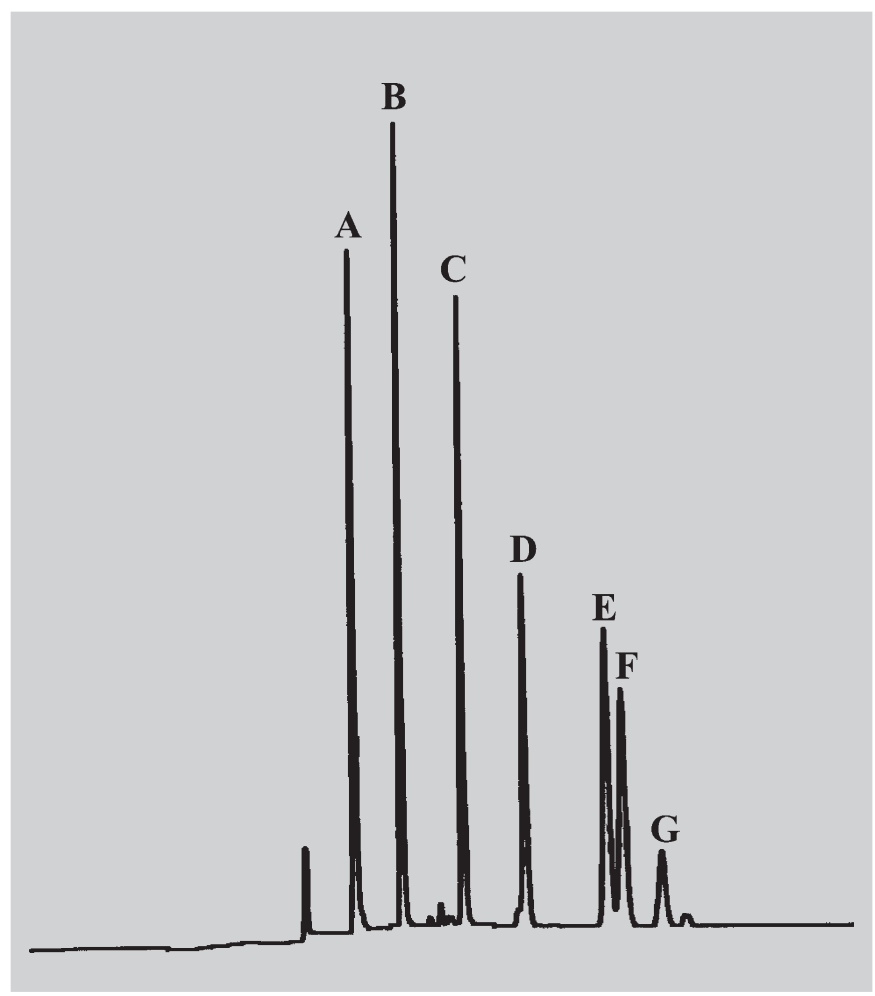

FIGURE 2 - HPLC chromatogram of foranoheliangolides from Lychnophora with coumarin as internal standard. (A) coumarin; (B) goyazensolide; (C) centratherin; (D) lychnopholide; (E) 15 $\alpha$-4,5-dihydroeremantholide C; (F) 15-deoxygoyazensolide; (G) eremantholide C. Chromatographic conditions in the text. 
necessary to introduce alkylthiols containing a large chromophore by Michael addition to the $\alpha$-methylenebutyrolactone function (Leven, Willhun, 1987; Dolman et al., 1992). The determinations developed in this study do not require this treatment, and good resolution is obtained at room temperature.

A GC method for quantification of furanoheliangolides was also developed. With our procedure, a good separation of the lactones is possible within $28 \mathrm{~min}$ (Figure 3 ), using coumarin as the internal standard. Temperature gradient optimization was necessary.

Peak area linearity for the RP-HPLC and GC methods was checked by analyzing the samples at various concentrations. Linear relationships were found between the peak areas and the analyte concentrations. For the HPLC method developed, good linearity was obtained for all lactones between 1.5 and $150 \mu \mathrm{g} \mathrm{mL}^{-1}$. Calibration plots and regression data for all analytes were linear $(r>0.997)$ at the tested concentrations. For the GC analysis between 0.15 and $1.5 \mu \mathrm{g} \mathrm{mL}^{-1}$, calibration plots and regression data for all lactones were linear $(r>0.996)$ at the tested concentrations. Each calibration level was run in triplicate. The average slopes and $y$-intercepts of the regression line, and correlation coefficients $(r)$ are shown in Table I.

\section{CONCLUSIONS}

The data demonstrated that the analytical methodologies using RP-HPLC and GC developed in this study were suitable for the separation and quantification of the furanoheliangolides most common in the genus Lychnophora. These systems are applicable for detection and quantification of these metabolites without any prior derivatization. Both systems showed a good resolution for all tested lactones and all peaks were resolved in GC, and in RP-HPLC at room temperature.

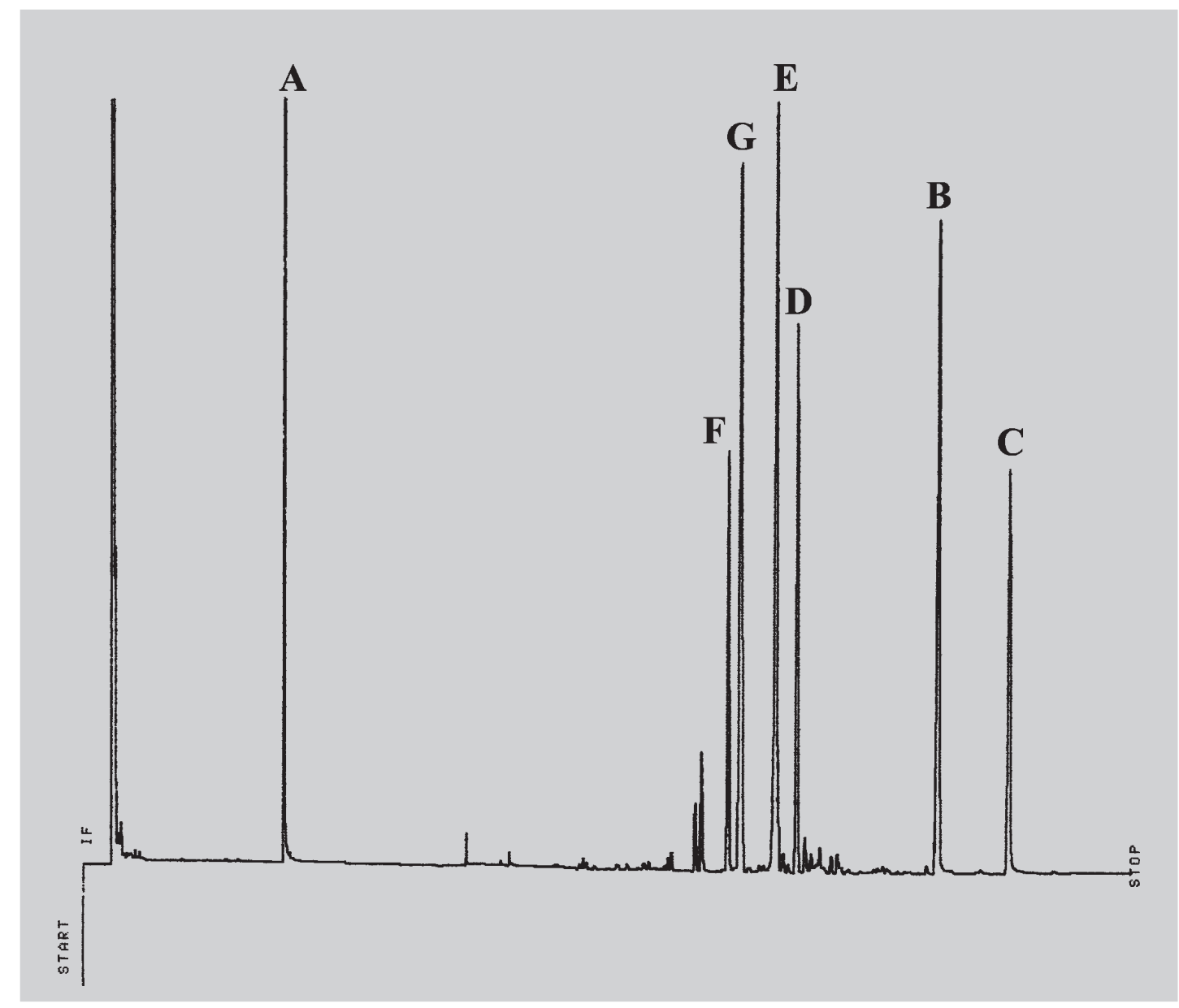

FIGURE 3 - GC chromatogram of furanoheliangolides from Lychnophora with coumarin as the internal standard. (A) coumarin; (B) goyazensolide; (C) centratherin; (D) lychnopholide; (E) 15a-4,5-dihydroeremantholide C; (F) 15deoxygoyazensolide; $(\mathbf{G})$ eremantholide $\mathrm{C}$. Chromatographic conditions in the text. 
TABLE I - Linear regression equations for quantitative analysis of sesquiterpene lactones by HPLC and GC

\begin{tabular}{|c|c|c|c|c|c|c|}
\hline \multirow[b]{2}{*}{ Analyte } & \multicolumn{3}{|c|}{ HPLC } & \multicolumn{3}{|c|}{ GC } \\
\hline & Regression equation & $r$ & $\begin{array}{l}\text { Concentration } \\
(\mathrm{mg} / \mathrm{mL})\end{array}$ & Regression equation & $r$ & $\begin{array}{l}\text { Concentration } \\
(\mathrm{mg} / \mathrm{mL})\end{array}$ \\
\hline Goyazensolide & $Y=0.10155+1.8808 x$ & 0.9984 & $1.5-150$ & $y=-0.60223+45.4981 x$ & 0.9993 & $30.15-1.5$ \\
\hline Centratherin & $Y=0.08961+1.6156 x$ & 0.9976 & $1.5-150$ & $y=-0.45632+41.6328 x$ & 0.9996 & $6 \quad 0.15-1.5$ \\
\hline Lychnopholide & $Y=0.01921+1.1836 x$ & 0.9984 & $1.5-150$ & $y=0.01031+46.7642 x$ & 0.9977 & $7 \quad 0.15-1.5$ \\
\hline Eremantholide C & $Y=0.01921+0.4206 x$ & 0.9986 & $1.5-150$ & $y=-0.10789+13.7212 x$ & 0.9997 & $7 \quad 0.15-1.5$ \\
\hline 15-Deoxygoyazensolide & $Y=0.06008+1.2065 x$ & 0.9987 & $1.5-150$ & $y=0.05166+42.3369 x$ & 0.9960 & $0.15-1.5$ \\
\hline $15 a-4,5-$ & $Y=0.05586+1.3475 x$ & 0.9980 & $1.5-150$ & $y=-0.36854+33.0132 x$ & 0.9991 & $0.15-1.5$ \\
\hline Dihydroeremantholide C & & & & & & \\
\hline
\end{tabular}

$y=$ peak area of lactone/peak area internal standard, $x=$ calculated mass, $r=$ correlation coeficient.

\section{RESUMO}

\section{Quantificação dos furanoeliangolidos por HPLC e CG}

Neste trabalho são descritos o desenvolvimento e comparação de dois métodos analíticos (CLAE e CG) para quantificação dos furanoeliangolidos mais comuns em Lychnophora. Ambos os métodos são sensiveis e adequados para a quantificação desses metabólitos.

UNITERMOS: Furanoeliangolidos. Lychnophora. CLAE. $C G$

\section{ACKNOWLEDGEMENTS}

The authors are grateful to FAPESP for financial support and to Tatiana Fonseca for language review.

\section{REFERENCES}

BOHLMANN, F.; ZDERO, C.; ROBINSON, H.; KING, R. M. Naturally-occurring terpene derivatives. 393. ahumulene derivatives including a sesquiterpene acid with a rearranged carbon skeleton from Lychophora columnaris. Phytochemistry, Oxford, v.21, n.3, p.685689, 1982.

BORELLA, J. C.; LOPES, J. L. C.; LEITÃO-FILHO, H. D.; SEMIR, J.; DIAZ, J. G.; HERZ, W. Eudesmanolides and 15-deoxygoyazensolide from Lychnophora pseudovilasossima. Phytochemistry, Oxford, v.31, n.2, p.692-695, 1992.
CERQUEIRA, M. B. S.; SOUZA, J. T.; AMADO-JÚNIOR, R.; PEIXOTO, A. B. F. Ação analgésica do extrato bruto aquoso do caule e das folhas da Lychnophora ericoides Mart. (arnica). Cienc. Cult., São Paulo, v.39, n.5/6, p.551$553,1987$.

DE OLIVEIRA, A. B.; SAÚDE, D. A.; PERRY, K. S.; DUARTE, D. S.; RASLAN, D. S.; BOAVENTURA, M. A. D.;. CHIARI, E. Trypanocidal sesquiterpene lactones from Lychnophora species. Phytother. Res., Bognor Regis, v.10, n.4, p.292-295, 1996.

DOLMAN, D. M.; KNIGHT, D. W.; SALAN, U.; TOPLIS, D. A quantitative method for the estimation if partenolide and other sesquiterpene lactones containing amethylenebutyrolactone functions present in feverfew, Tanacetum partenium. Phytochem. Anal., Bognor Regis, v.3, n.1, p.2631, 1992.

LEVEN, W.; WILLUHN, G. Sesquiterpene lactones from Arnica chamissonis Less. 6. Identification and quantitative determination by high performance liquid and gas chromatography. J. Chromatogr., Amsterdam, v.410, n.2, p.329-342, 1987.

LUNARDELLO, M. A.; TOMAZ, J. C.; VICHNEWSKI, W.; LOPES, J. L. C.; GUTIERREZ, A. B.; DIAZ, J. G.; HERZ, W. Sesquiterpene lactones and flavonoids from Eremanthus mattogrossensis and Eremanthus eriopus.J. Braz. Chem. Soc., São Paulo, v.6, n.3, p.307-311, 1995.

PASSREITER, C. M. Quantification of sesquiterpene lactones in leaves of Neurolaena lobata. Phytochem. Anal., Bognor Regis, v.9, n.2, p.67-70, 1998. 
RÜNGELER, P.; CASTRO, V.; MORA, G.; GÖREN, N.; VICHNEWSKI, W.; PAHL, H. L.; MERFORT, I.; SCHMIDT, T. J. Inhibition of transcription factor NF-kB by sesquiterpene lactones: a proposed molecular mechanism of action. Bioorg. Med. Chem., Oxford, v.7, n.11, p.2343-2352, 1999.

SEMIR, J. Revisão taxonômica de Lychnophora Mart. (Vernoniae: Compositae). Campinas, 1991. 515 f. (Tese de Doutorado - Instituto de Biologia - Universidade Estadual de Campinas).
VICHNEWSKI, W.; TAKAHASHI, A. M.; NASI, A. M. T.; GONÇALVES, D. C. R. G.; DIAS, D. A.; LOPES, J. N. C.; GOEDKEN, V. L.; GUTIÉRREZ, A. B.; HERZ, W. Sesquiterpene lactones and other constituents from Eremanthus seidelii, E. goyazensis and Vanillosmopsis erythropappa.Phytochemistry, Oxford, v.28, n.5, p.14411451, 1989.

Recebido para publicação em 02 de dezembro de 2002. 